\title{
Impact of air pollution on forest stands in the vicinity of Wodzisław Śląski and Rybnik, Poland
}

\author{
Joanna Barniak ${ }^{1}$, Agnieszka Jureczko \\ ${ }^{1}$ AGH University of Science and Technology, Faculty of Geology, Geophysics and Environment Protection; \\ al. A. Mickiewicza 30, 30-059 Krakow; e-mail: barniak@geol.agh.edu.pl; ORCID ID: 0000-0001-7676-6668
}

(C) 2019 Authors. This is an open access publication, which can be used, distributed and reproduced in any medium according to the Creative Commons CC-BY 4.0 License requiring that the original work has been properly cited.

Received: 21 October 2019; accepted: 10 December 2019; first published online: 30 December 2019

\begin{abstract}
Tree-ring analysis was used to investigate the impact of air pollution on forest stands in southern part of the Upper Silesia region of southern Poland. Four about 120 years old Scots pine stands located near Wodzisław Śląski and Rybnik were selected for study and 20 increment core samples from each stand were taken. All study stands were selected based upon their considerable exposure to air and dust pollution.

The results of dendrochronological analysis showed strong and significant reductions in tree ring growth especially during the period from 1960 to 1990 . A significant number of trees with reductions (85\%) was observed in two Scots pine stands both of which are directly exposed to air pollution from mine-owned coking plant and power and heating plants. Since 1990s the improved growth of these pines was clearly noted. A comparison for the period 1970 to 1990 for stands located west from the main emitters' versus stands east and directly exposed found fewer trees with growth reductions (ca. 40\%). At the beginning of the $21^{\text {st }}$ century, a large number of trees in these western stands were observed with growth reductions between 50 and $60 \%$. Probably, these trees were affected by air pollution from a nearby power plant located immediately across the border in the Czech Republic. Relationships between periods of severe reductions in ring width growth or missing rings were noted in a large percentage of pine trees in all four stands; these cross-stand relationships suggested common weather related impacts. Missing rings were noted in 1956, 1963, 1968, 1970, 1971, 1973, 1976 and 1979.
\end{abstract}

Keywords: dendroecology, Pinus sylvestris, air pollution, Southern Poland

\section{INTRODUCTION}

The tree growth, and consequently the width of a ring developed during the growing season, is affected by a number of biotic and abiotic factors (Schweingruber 1996). Thanks to the information recorded in annual increments of trees we have an archive of data that can be examined in light of known abiotic and biotic stress factors such as defoliation, drought, frost, and air pollutants. A myriad of air pollutants formed during the industrial processes can affect the tree growth and development both acutely and chronically (Farrar et al. 1977, Greszta 1987). Trees growing within the range of industrial emissions have been observed to have narrower annual increments or, in extreme cases, have no increment at all in a given year (missing ring) (Schweingruber 1986, Nöjd \& Reams 1996, Malik et al. 2009, Rydval \& Wilson 2012).

Dendrochronological methods are often used in studies of the impact of industrial emissions on trees and stands (Zielski 1992, Oleksyn et al. 1993, Szychowska-Krąpiec \& Wiśniowski 1996, Szychowska-Krąpiec 1997, Juknys et al. 2003, Danek 2007, 2008, Sensuła et al. 2015a). Most often, these studies find an abrupt decline and a slower recovery in growth with the onset and cessation of air pollutant exposure. With the absence of measurement data for emission of noxious compounds, the 
results of dendrochronological analyses are a valuable source of information on the condition of the environment (Malik et al. 2009, Barniak \& Krąpiec 2016). The results of dendrochronological analysis allowed one to observe the recovery of trees associated with an improvement of the environment (Krąpiec \& Szychowska-Krąpiec 2001, Danek 2007, Sensuła et al. 2015a, Sensuła et al. 2016).

Intensive industrial growth in the Upper Silesia related to coal mining and use, particularly in 1960-1990, had a detrimental impact on the region's environment, including the forests. Studies on the impact of this industrial activity on the trees and stands located near the Tarnowskie Góry Chemical Plant and Miasteczko Śląskie Zinc Works (Malik et al. 2009, 2012) demonstrated an adverse impact of this activity on tree growth and stand condition in the past decades. Similarly, the pine stands in the area of the Eaziska Power Plant, which has been operated since 1917, have also shown strong negative impacts to tree and stand condition (Sensuła et al. 2015b).

Many industrial plants (mines, coking plants, power plants) were built in the vicinity of Wodzisław Śląski and Rybnik in the $20^{\text {th }}$ century (Cichy 2011, Frużyński 2012). The region was also affected by the Dziećmorowice Power Plant in Czech Republic. As a result of prevailing western winds (System informacji o jakości powietrza..., 2011), the emissions of gaseous pollutants could affect the condition of local forests.

As a result of the known industrial activity in the Upper Silesia and adjacent areas, this dendrochronological study aims at documenting the impact of this activity on annual increment changes in the growth of pines. The specific goals of this study are to document the timing, duration, and extent of impact on Scots pine trees in this area.

\section{STUDY AREA}

The area of the study is located in the southern part of the Silesian Province; it is situated in the Rybnik Plateau mesoregion that is a part of the Silesian Upland macroregion of Poland (Kondracki 2002). This is a region of mixed forest stands of Scots pine and hardwoods, agricultural fields, and a region with a 100 -year history of industrial activity including intensive coal mining and, more recently, coking and power plants. All study forest stands are in the Rybnik Forest Range (forest districts: Chwałęcice, Ornontowice, Szczotki, Wodzisław) (Fig. 1, Tab. 1).

Meteorological and air quality observations were collected during the 2001-2010 decade at Polish (IMGW-PIB) and Czech weather stations. During that period, an annual mean temperature of $9^{\circ} \mathrm{C}$ was observed, and an annual mean precipitation ranged between 636 to $824 \mathrm{~mm}$. The western winds prevail during the year (System informacji o jakości powietrza..., 2011).

As shown in Figure 1, there are currently four coal mines, "Chwałowice", "Jankowice", "Marcel", and "Rydultowy-Anna" in operation in the Rybnik Coal Basin (Frużyński 2012). The recently closed "Marcel-Ruch 1 Maja" mine was in operation for over 100 years. Its operation transformed the hydrogeological conditions down to the depth of $1000 \mathrm{~m}$ and also lowered the water table and dried the rock mass down to depths between 200-400 m (Paczyński \& Sadurski 2007). Coal mining also caused air pollution as a result of the dust blown off the large waste dumps associated with each mine.

This coal mining supported the development of the power plants and combined heat and power plants (CHP) found in this area. The Rybnik Power Plant is located in the northwest part of the city at the Rybnik Reservoir (Fig. 1). It was built in 1972-1974, the stacks are 260 and 300-m high. The Marcel CHP Plant (stack height $80 \mathrm{~m}$ ) built in 1908 is located at the premises of Marcel Coal Mine in Radlin. The operation of these power plants has resulted in air pollution (Lokalny program rewitalizacji..., 2009).

The Radlin Coking Plant, located in the city of Radlin, some $5 \mathrm{~km}$ north of Wodzisław Śląski (Fig. 1), is also a major source of air pollution. Plant construction started in 1910 and it was commissioned in the same year. Over more than a century of operation, the plant has produced 50 million tons of coke (Cichy 2011). Coke and gas production peaked in 1971. In 1990, the Radlin Coking Plant made it to the list of 80 plants most noxious to the environment, and in 1992 it joined the "Clean Production" programme. The Poland's most modern coke gas desulphurization system was commissioned at the plant in 1999. The greatest emissions of pollutants took place between 1980 and 1990 (Fig. 2). 


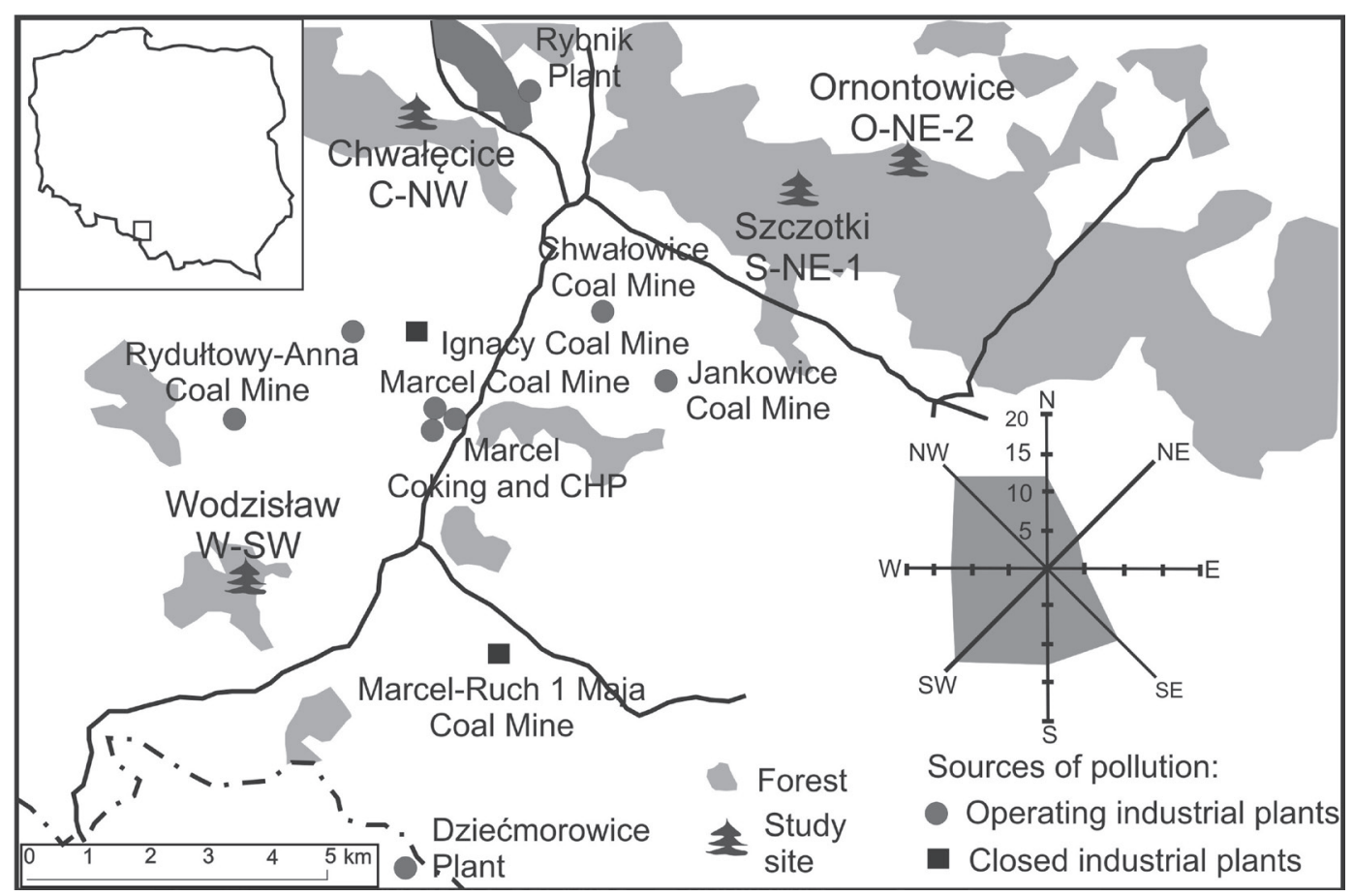

Fig. 1. Location of the study sites and the main pollution sources. Wind rose in the investigated area is also shown (System informacji o jakości powietrza..., 2011)

Table 1

Basic information about the four study sites (FMBF - fresh mixed broadleaved forest, FCF - fresh coniferous forest; see Figure 1 for sites locations)

\begin{tabular}{|l|c|c|c|c|c|}
\hline Study site name & $\begin{array}{c}\text { Study site code } \\
\text { name }\end{array}$ & Elevation [m] & $\begin{array}{c}\text { Average age of } \\
\text { trees [years] }\end{array}$ & Habitat type & Soil group \\
\hline Chwałęcice & C-NW & 225 & 110 & FMBF & arenosols \\
\hline Szczotki & S-NE-1 & 228 & 130 & FCF & arenosols \\
\hline Ornontowice & O-NE-2 & 231 & 120 & FMBF & arenosols \\
\hline Wodzisław & W-SW & 210 & 120 & FMBF & arenosols \\
\hline
\end{tabular}

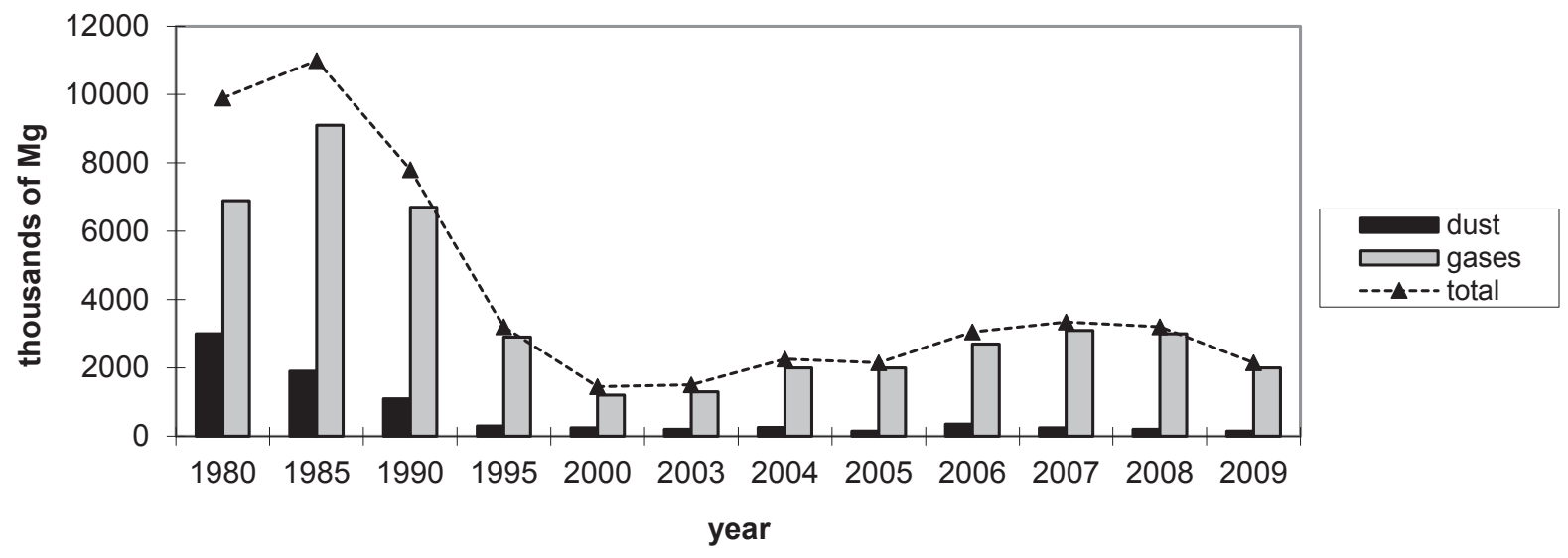

Fig. 2. The amount of emission from Radlin Coking Plant in the years 1980-2009 (Cichy 2011) 
About $20 \mathrm{~km}$ south of Wodzisław Śląski the Dziećmorowice Power Plant is located and the adjacent Ostrava-Karvina Coal Basin, as well. The Czech plant generating power and heat was built in 1971-1976. It is the biggest power plant in the country and a large emitter of pollutants. Filters were installed on the stacks in 1998 to reduce air pollution. The plant's stacks reach $259 \mathrm{~m}$ and can be seen even from Wodzisław and Rybnik.

\section{MATERIAL AND METHODS}

The dendrochronological studies were performed in four similar Scots pine (Pinus sylvestris L.) stands, about 120 years old and located in the Rybnik Forest Range (Tab. 1). The sites are located within the $10 \mathrm{~km}$ radius from the nearest sources of pollutants (Fig. 1). Due to the prevailing western winds, two of them (Szczotki - site code S-NE-1 and Ornontowice - site code O-NE-2) are directly affected by the pollution from the emitters located in Wodzisław and Rybnik. Sites Wodzisław (site code W-SW) and Chwałęcice (site code C-NW) are located west of those emitters. The site W-SW is the closest to the Dziećmorowice Power Plant in Czech Republic. The tree stands are classified as permanently damaged by industrial activity (source: forest surveys).

Standard dendrochronological methodology was applied in the field and laboratory portions of this study (Zielski \& Krąpiec 2004, Barniak \& Krąpiec 2016). At the end of the 2015 growing season, twenty breast height increment cores were taken from pine trees on each site using an increment borer. Dominant trees without obvious damage and with healthy canopies were selected for coring. Measurements of annual increments were made to $0.01 \mathrm{~mm}$ accuracy for each sample core using a DENDROLAB device linked to a computer to record the results. The resultant increment sequences were correlated with each other using PROT1 software (a package of TREE RINGS programs, Krawczyk \& Krapiec 1995) based on the value $t$ (Baillie \& Pilcher 1973) and coefficient of correlation $r$. The local chronology was determined based on the individual sequences with the highest correlation $(t>4.5)$ that did not show abrupt decreases of annual increments. The chronology covers the period from 1902 to 2015, and includes 11 individual sequences. The chronology assumption of correctness was verified using the COFECHA software (Holmes 1986). Then, the reduction of annual increments was determined using Quercus software for each individual sequence, which is not a component of the mean (Walanus 2005). The methodology suggested by Schweingruber (1986) was applied, wherein the reduction of annual increments $R$ (expressed in percentages) is calculated as the ratio of the sum of the width of reduced increments to the sum of the width of non-reduced increments. The reduction size is defined by three classes: RI (30-50\%) - low reductions, RII (50-70\%) - strong reductions, RIII (above 70\%) - very strong reductions.

\section{RESULTS}

The four study sites have a large number of trees with an annual increment reduction greater than 90\% (Fig. 3). The fewest number of pines with reductions was found at site C-NW (up to 55\%) and very strong reductions were not found there. Annual reductions in increment were detected in 1965-1990 and 1995-2015. The reductions at site W-SW happened during the same two periods, but were more severe (class RIII) and occurred in a greater number of trees. At site S-NE-1, the reductions of annual increments were recorded between 1963 and 1985. The greatest number of pines with reductions was observed between 1965 and 1975. A similar distribution in growth reductions was found at the site O-NE-2, where the most reductions took place between 1963 and 1990. Reductions in annual increment were observed in most of the trees, reductions extended over almost all of this 27-year period, the proportion of reductions in classes RII and RIII were the highest in the four study site. Beginning around 1990, the number of pines with reductions on the sites S-NE-1 and O-NE-2 fell and remained low. On the sites C-NW and W-SW, after a period of short improvement of increment growth in those same years, the number of trees with reductions actually increased to $60 \%$. These are mainly class I and II reductions at site C-NW; in contrast, class II and III reductions dominated at site W-SW. The greatest number of trees with the highest-degree of reductions and with a significant number of trees with missing rings was recorded in the 1970s (Tab. 2). 


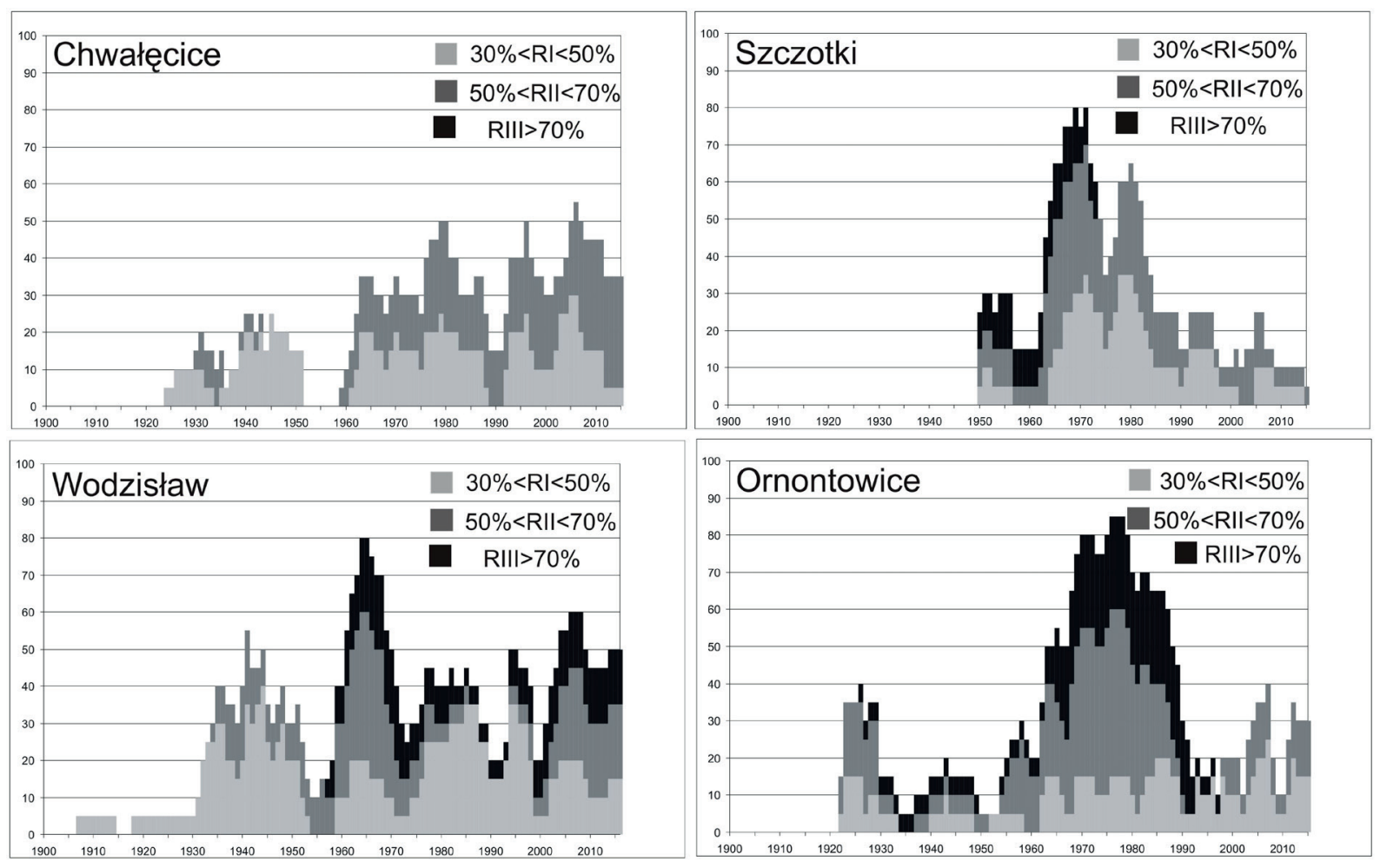

Fig. 3. Growth reductions at pines in respective classes. Explanations: low $(30 \%<R I<50 \%)$ - light grey, strong $(50 \%<R I I<70 \%)-$ - grey, very strong $(R I I I>70 \%)$ - black

Table 2

Missing rings identified in samples at study sites

\begin{tabular}{|c|c|c|c|c|c|c|}
\hline Study site name & $\begin{array}{l}\text { Study site } \\
\text { code name }\end{array}$ & Sample code & $\begin{array}{c}\text { Missing ring } \\
\text { year }\end{array}$ & $\begin{array}{c}\text { Reduction } \\
\text { range [years] }\end{array}$ & $\begin{array}{c}\text { Value of } \\
\text { reduction [\%] }\end{array}$ & $\begin{array}{l}\text { Class of } \\
\text { reduction }\end{array}$ \\
\hline \multirow{3}{*}{ Chwałęcice } & \multirow{3}{*}{ C-NW } & $2 \mathrm{C} 1 \_2$ & 1970 & $1970-1974$ & 37.5 & RI \\
\hline & & 2C1_7 & 1963 & $1963-1966$ & 31.2 & RI \\
\hline & & $2 \mathrm{C} 1 \_8$ & 1963 & $1957-1979$ & 52.0 & RII \\
\hline \multirow{3}{*}{ Szczotki } & \multirow{3}{*}{ S-NE-1 } & $2 S 2 \_8$ & 1971 & $1965-1983$ & 49.1 & RI \\
\hline & & $2 S 2 \_8$ & 1979 & $1965-1983$ & 49.1 & RI \\
\hline & & $2 \mathrm{~S} 2 \_11$ & 1968 & 1964-1971 & 38.1 & RI \\
\hline \multirow{5}{*}{ Ornontowice } & \multirow{5}{*}{ O-NE-2 } & 2O3_1 & 1956 & - & - & - \\
\hline & & 2O3_7 & 1979 & $1968-1990$ & 69.3 & RII \\
\hline & & $2 \mathrm{O} 3 \_8$ & 1976 & $1966-1982$ & 63.3 & RII \\
\hline & & 2O3_10 & 1979 & $1975-1983$ & 55.0 & RII \\
\hline & & 2O3_14 & 1976 & $1964-1987$ & 57.7 & RII \\
\hline \multirow{5}{*}{ Wodzisław } & \multirow{5}{*}{ W-SW } & 2W4_8 & 1963 & $1940-1967$ & 65.3 & RII \\
\hline & & 2W4_9 & 1963 & $1962-1966$ & 30.7 & RI \\
\hline & & 2W4_16 & 1973 & $1960-1984$ & 68.6 & RII \\
\hline & & 2W4_18 & 1960 & $1960-1971$ & 70.3 & RIII \\
\hline & & 2W4_20 & 1963 & $1960-1970$ & 74.8 & RIII \\
\hline
\end{tabular}




\section{DISCUSSION}

In the 1970s the industry in the region grew fast. The Rybnik Power Plant was built, and at that time it did not have any equipment limiting the emission of pollutants to the atmosphere. The flue gas desulphurization system, which could improve the condition of the environment, was not built until 1991 and it covered only four of the plant's eight units (Jarzębski 1997). Coal mining expanded at the same time, a continuation of the process initiated in the previous decade. As a result, coal output increased, varying among the different mines, from 1 to 2.5 million tons a year (Mrowiec 1974, Rojek 2005, Cichy 2008, Adamczyk 2015). In 1988, total coal output exceeded 3 million tons (Adamczyk 2015). The 1970s mark the growth of the Radlin Coking Plant (Cichy 2011). Its peak emissions occurred in 1985; however, significantly reduced emissions were not achieved until after 1990 (see Fig. 2). The Marcel CHP had an adverse effect on the environment of the region; since 1976, its processing and burning activities resulted in the emission of about 20 thousand tons of dust and 8 thousand tons of sulphur dioxides per year. In 1979, modern dust removal equipment was installed and its installation resulted in a $98 \%$ reduction in emission (Cichy 2008). Also, in 1976, the Dziećmorowice Power Plant came on line (www.cez.cz).

In terms of tree ring increments at the four study sites, the 1980s were characterized by the widespread presence of narrow-rings. In many cases, the narrowing of rings began prior to 1980 .

Beginning in the second half of the 1980s, the condition of study trees gradually started to improve as evidenced by wider annual increments (Fig. 3). More rigorous emission standards for noxious gaseous compounds and installation of dust removal equipment improved the air quality. It should be emphasized that the ring width increases observed in the the 50 study trees also reflect the regional trend noted in the 1990s (Szychowska-Krąpiec 2001, Danek 2007, Krąpiec \& Sensuła et al. 2015a, Sensuła et al. 2016).

From 2000 to 2015, the number of trees demonstrating reductions in ring increment increased on two (W-SW and C-NW) of the four sites, reaching $60 \%$ of examined pines. The tree stand on the site W-SW was undoubtedly affected by pollution emitted from Czech Republic when in 2011 the largest emission of noxious compounds to the atmosphere took place at the Dziećmorowice Power Plant (Air pollution fact sheet, 2013). On the other hand, the modernization of the Radlin Coking Plant between 2007 and 2008 and limiting the coke production in 2008-2009 (Cichy 2011), as well as the modernization of boilers at the Marcel CHP in 2007, appeared to have improved the tree and stand condition on sites S-NE-1 and O-NE-2 (Cichy 2008). These plant modifications reduced the emissions of dust and air pollutants, but did not eliminate them entirely.

The 16 trees examined in this study had missing rings (Tab. 2); their occurrence largely coincided with the periods of the greatest reductions of annual increments. During the 1970s on site O-NE-2 missing rings were found in 4 of the 20 sample trees. The fewest trees with missing rings were found on the site C-NW ( 3 samples), a site that also had the fewest trees with reductions. In addition to the effect of dust and air pollutants, missing rings could have been the result of adverse weather. After an exceptionally severe winter in 1962 and a hot summer during the next vegetation season (Opała \& Mendecki 2014), no increment in 1963 was found in 5 trees on the sites W-SW and C-NW. The 1978/79 winter was similarly cold, and no increment in 1979 was found in several trees (Tab. 2). The combined effect of adverse weather and large amounts of emissions in the 1970s resulted in a significant growth impacts on these pine stands (see Barniak 2009, Malik et al. 2009).

\section{CONCLUSIONS}

1. The time and spatial distribution of reduction of annual increments obtained as a result of the studies reflects the adverse effects of air pollution on the natural environment.

2. The gaseous pollutants emitted by the region's industry contributed to the decrease of the width of annual increments in pines, particularly in the 1970s and 1980s.

3. A significant number of trees with reductions and the highest reduction degrees were found on the sites situated along the directions of prevailing winds. 
4. The largest reductions, also in recent years, were observed on the site closest to the Dziećmorowice Power Plant.

5. In the second half of the $20^{\text {th }}$ century, the combination of natural and anthropogenic causes probably intensified the degree of ring reduction and increased the number of trees with reductions.

6. The missing rings coincide with periods with the largest number of trees with reductions. There relationship between the occurrence of missing rings and adverse weather has been noticed.

This work was financially supported by the AGH University of Science and Technology as a part of statutory project no. 16.16.140.315.

The authors are grateful to Professor Tom Hinckley for his valuable comments and amendments.

\section{REFERENCES}

Adamczyk A., 2015. Kopalnia Wegla Kamiennego Rydułtowy-Anna 1945-2014. ART DRUK, Rydułtowy.

Air pollution fact sheet Czech Republic, 2013. European Environment Agency, [on-line:] www.eea.europa.eu/themes/ air/air-pollution-country-fact-sheets [access: 8.12.2016].

Baillie M.G.L. \& Pilcher J.R., 1973. A simple crossdating program for tree-ring research. Tree-Ring Bulletin, 33, 7-14.

Barniak J. \& Krąpiec M., 2009. Wpływ działalności przemysłowej na drzewostany sosnowe w rejonie Tarnobrzega w świetle analizy dendrochronologicznej. Sylwan, 153, 825-835.

Barniak J. \& Krąpiec M., 2016. The tree-ring method of estimation of the effect of industrial pollution on pine ( $P i$ nus sylvestris L.) tree stands in the northern part of the Sandomierz Basin (SE Poland). Water, Air and Soil Pollution, 227, 5, 166.

CEZ Group - Dětmarovice, https://www.cez.cz/en/power-plants-and-environment/coal-fired-power-plants/cr/ detmarovice [access: 4.12.2016].

Cichy K., 2008. 100 lat Elektrowni Marcel w Radlinie. Elektrociepłownia Marcel Sp. z o.o., Radlin.

Cichy K., 2011. 100 lat Koksowni Radlin. Kombinat Koksochemiczny „Zabrze” s.a., Radlin.

Danek M., 2007. The influence of industry on Scots pine stands in the southeastern part of the Silesia-Krakow Upland (Poland) on the basis of dendrochronological analysis. Water, Air and Soil Pollution, 185, 265-277.

Danek M., 2008. Wpływ działalności przemysłowej na szerokość przyrostów rocznych sosen (Pinus sylvestris L.) w rejonie Olkusza. Sylwan, 11, 56-62.

Farrar J.F., Relton J. \& Rutter A.J., 1977. Sulphur dioxide and the scarcity of Pinus sylvestris in the industrial Pennines. Environmental Pollution, 14, 63-68.

Frużyński A., 2012. Kopalnie wegla kamiennego w Polsce. Księży Młyn Dom Wydawniczy Michał Koliński, Łódź.
Greszta J., 1987. Wpływ przemysłowego zanieczyszczenia powietrza na lasy. Wyd. SGGW-AR, Warszawa.

Holmes R.L., 1986. Quality control of crossdating and measuring. User's manual for computer program COFECHA. [in:] Holmes R.L., Adams R.K. \& Fritts H.C. (eds.), Tree rings chronologies of western North America: California, eastern Oregon and northern Great Basin., Chronology Series, 6, University of Arizona, Tuscon, 41-49.

Jarzębski L. (red.), 1997. Raport o stanie środowiska w województwie katowickim w latach 1995-1996. Biblioteka Monitoringu Środowiska, PIOŚ, Katowice - Warszawa.

Juknys R., Vencloviene J., Stravinskiene V., Augustaitis A. \& Bartkevicius E., 2003. Scots pine (Pinus sylvestris L.) growth and condition in a polluted environment: from decline to recovery. Environmental Pollution, 125, 2, 205-212.

Kondracki J., 2002. Geografia regionalna Polski. Wydawnictwo Naukowe PWN, Warszawa.

Krawczyk A. \& Krąpiec M., 1995. Dendrochronologiczna baza danych. [in:] Komputerowe wspomaganie badań naukowych: II Krajowa Konferencja, II KK KOWBAN '95, Wrocław, 14-16 grudnia 1995 r.: materiały, „Sudety”, Wrocław, 247-252.

Krąpiec M. \& Szychowska-Krąpiec E., 2001. Tree-ring estimation of the effect of industrial pollution on pine ( $P i$ nus sylvestris) and fir (Abies alba) in the Ojców National Park (Southern Poland). Nature Conservation, 58, 33-42.

Lokalny program rewitalizacji miasta Rybnika na lata 20072013 [Rybnik local revitalization programme], 2009. Wydział Rozwoju, Promocji Gospodarczej i Integracji Europejskiej Urzędu Miasta Rybnika, Rybnik, on-line: www.bip.um.rybnik.eu [access: 3.11.2016].

Malik I., Danek M., Danek T., Krąpiec M. \& Wistuba M., 2009. Zanieczyszczenie atmosfery przez zakłady przemysłowe położone w północnej części Wyżyny Śląskiej zapisane w przyrostach rocznych sosny zwyczajnej. Czasopismo Geograficzne, 80, 4, 257-274.

Malik I., Danek M., Marchwińska-Wyrwał E., Danek T., Wistuba M. \& Krąpiec M., 2012. Scots pine (Pinus sylvestris L.) growth suppression and adverse effects on human health due to air pollution in the Upper Silesian Industrial District (USID), southern Poland. Water Air Soil Pollution, 223, 3345-3364.

Mrowiec A., 1974. Kopalnia "Chwałowice” i jej załoga na tle rozwoju górnictwa ziemi rybnickiej 1903-1973. PWN, Kraków.

Nöjd P. \& Reams G.A., 1996. Growth variation of Scots pine across a pollution gradient on the Kola Peninsula, Russia. Environmental Pollution, 93, 3, 313-326.

Oleksyn J., Fritts H.C. \& Hughes M.K., 1993. Tree-ring analyses of different Pinus sylvestris provenances, Quercus robur, Larix decidua and $L$. decidua x L. kaempferi affected by air pollution. Arboretum Kórnickie, 38, 87-111.

Opała M. \& Mendecki M.J., 2014. An attempt to dendroclimatic reconstruction of winter temperature based on multispecies tree-ring widths and extreme years chronologies (example of Upper Silesia, Southern Poland). Theoretical and Applied Climatology, 115, 73-89.

Paczyński B. \& Sadurski A. (red.), 2007. Hydrogeologia regionalna Polski. T.2 Wody mineralne, lecznicze i termalne oraz kopalniane. Państwowy Instytut Geologiczny, Warszawa. 
Rojek H., 2005. 120 lat kopalni „Marcel” 100 lat Kopalnianej Stacji Ratownictwa Górniczego kopalni „Marcel”. Kopalnia Węgla Kamiennego „Marcel”, Radlin.

Rydval M. \& Wilson R., 2012. The impact of industrial $\mathrm{SO}_{2}$ pollution on north Bohemia conifers. Water Air and Soil Pollution, 223, 5727-5744.

Schweingruber F.H., 1986. Abrupt growth changes in conifers. IAWA Bulletin, 7, 4, 277-283.

Schweingruber F.H., 1996. Tree rings and environment: dendroecology. Paul Haupt Publishers, Bern.

Sensuła B., Opała M., Wilczyński S. \& Pawełczyk S., 2015a. Long- and short- term incremental response of Pinus silvestris $\mathrm{L}$. from industrial area nearby steelworks in Silesian Upland, Poland. Dendrochronologia, 36, 1-12.

Sensuła B., Wilczyński S. \& Opała M., 2015b. Tree growth and climate relationship: dynamic of Scots pine (Pinus sylvestris L.) growing in the near-source region of the combined heat and power plant during the development of the pro-ecological strategy in Poland. Water Air and Soil Pollution, 226, 220.

Sensuła B., Wilczyński S. \& Piotrowska N., 2016. Zastosowanie metod dendrochronologicznych oraz spektrometrycznych w monitorowaniu drzewostanów sosnowych na obszarach przemysłowych. Sylwan, 160, 9, 730-740.
System informacji o jakości powietrza na obszarze Pogranicza Polsko-Czeskiego w rejonie Ślaska i Moraw [Air Quality Information System in the area of Polish-Czech Borderline in the Moravia and Silesia region], 2011. IMGW-PIB, [on-line:] http://www.air-silesia.eu/files/file/air_silesia/ raport/AirSilesia_raport_1_.pdf [access: 3.11.2016].

Szychowska-Krąpiec E., 1997. Ocena wpływu zanieczyszczeń przemysłowych na drzewostany sosnowe Puszczy Niepołomickiej i Borów Nowotarskich w świetle analizy dendrochronologicznej. Geologia: kwartalnik Akademii Górniczo-Hutniczej, 23, 4, 389-406.

Szychowska-Krąpiec, E. \& Wiśniowski Z., 1996. Tree-ring analysis of Pinus sylvestris as a method to assess the industrial pollution impact on the example of Police chemical factory (NW Poland). Geologia: kwartalnik Akademii Górniczo-Hutniczej, 22, 3, 281-299.

Walanus A., 2005. Program Quercus. Instrukcja obsługi. Kraków.

Zielski A., 1992. Dendrochronological studies on pines growing under the influence of air pollution near the Pulp and Paper Factory in Kwidzyn, Poland. Lundqua Report, 34, 360-363.

Zielski A. \& Krąpiec M., 2004. Dendrochronologia. Wydawnictwo Naukowe PWN, Warszawa. 